\title{
Artigos/Articles
}

\section{Transforming Urban Education in São Paulo: Insights into a Critical-Collaborative School Project} Transformando a educação urbana em São Paulo: reflexões sobre um projeto de escola crítico-colaborativa

\author{
Fernanda Liberali
}

\section{ABSTRACT}

The world is experiencing a particularly tense moment which asks for a project that goes beyond the limiting situations posed by immediate reality. This condition considers the critical immersion of individuals in their known realities and broad emersion in multiple contexts of understanding, which may broaden their horizons of perception. Vygotsky and recent followers offer us a basis for rethinking our reality in a collaborative and critical search for forms of development beyond who we are. This article brings about projects developed with schools from very poor and wealthy communities of São Paulo, where participants act together to transform their life conditions.

Keywords: transformation; urban education; critical collaboration.

1. Pontifícia Universidade Católica de São Paulo, São Paulo - Brasil. https://orcid. org/0000-0001-7165-646X. E-mail: liberali@uol.com.br. 


\section{RESUMO}

O mundo está passando por um momento particularmente tenso que demanda projetos que ultrapassem as situações limitantes colocadas pela realidade imediata. Essa condição pressupõe a imersão crítica dos indivíduos em suas realidades conhecidas e emersões amplas em contextos múltiplos de compreensão, que possam ampliar seus horizontes de percepção. Vygotsky e seguidores recentes nos oferecem uma base para repensar nossa realidade em uma busca crítico-colaborativa por formas de desenvolvimento para além de quem somos. Este artigo discute projetos desenvolvidos com escolas de comunidades pobres e ricas de São Paulo, em que os participantes atuam juntos para transformar suas condições de vida.

Palavras-chave: transformação; educação urbana; colaboração crítica.

\begin{tabular}{|l|l|}
\hline "Meu canto é resistência & "My singing is resistance \\
No ecoar de um tambor & In the echo of a drum \\
Vêm ver brilhar & Come and see shine \\
Mais um menino que você abandonou" & One more boy you left behind" \\
(Samba Enredo da Escola de Samba & (Samba Enredo of the School of \\
Beija-Flor, 2018) & Samba Beija-Flor, 2018) \\
\hline
\end{tabular}

\section{Introduction}

The world is experiencing a particularly historically tense moment. International and national relations are marked by violence, disbelief, abandonment, despair, helplessness, dehumanization, exploitation. This could be understood by looking at the economic figures of 2017 and 2018, for example. According to a report released by Oxfam², on January $22^{\text {nd }}, 2018$, at the World Economic Forum in Davos, Switzerland, eighty two percent of the wealth generated in 2017 went to the richest one percent of the global population, while the 3.7 billion people who make up the poorest half of the world had no increase in their wealth. Similarly, in 2017, this agency had stated that the number of billionaires summed 2043 and it represented the greatest increase of

2. Available in: $<$ https://www.oxfam.org/en/pressroom/pressreleases/2018-01-22/richest1-percent-bagged-82-percent-wealth-created-last-year>. Acesso em: 18 jun 2018. 
billionaires in history. The agency considers that $1 / 7$ of their collective fortune could extinguish extreme poverty in the whole world.

In Brazil, according to data from the Gross Domestic Product (GDP) provided by Fundação Getulio Vargas (FGV) ${ }^{3}$, while economy advanced only $1,1 \%$ in 2017 (the number of ultra-rich rose and their fortune has increased $13 \%$ in the same year. Similarly, in January 2018, Oxfam stated that five Brazilian richest men hold the same wealth as the income of half the Brazilian population 4 .

These economic contradictions, along with the socio-cultural contradictions they create, seem to have been established as the basis of our living. In 1998, Pérez Gómez presented three central features of the postmodern society: the empire of the laws of free trade that regulate exchanges in the production, distribution and consumption; the political configuration in formal democracies with rule of law constitutionally governed; and the omnipresence of the mass media enhanced by technological development and its applications.

As Burbules and Torres (2004) point out, there is a concomitant unification of capital to a fragmentation of workers and other groups, which characterizes the trend towards globalization. They connect the devastating impact of global economic processes to the emergence of new cultural forms, global media and communication technologies and suggest the decrease of the concept of "citizenship".

Some of its drawbacks are materialized in the structural rates of unemployment; the erosion of labor and social exclusion; the increase in the gap between the rich and the poor; the increase in urban insecurity due to progressive violence; the serious threats to security, peace and development; the drug trafficking and mafias; the trade in weapons of mass destruction; the exploitation of natural resources; the growth in racism and repression; the transformation of prisons into profitable business; the intensification of a climate of fear and resistance; the use of age as a means for social division; a return to child labor; corruption,

3. See more at: https://economia.uol.com.br/noticias/bbc/2018/01/22/fortuna-de-bilionarios-brasileiros-cresce-13-e-chega-a-us-549-bilhoes-em-2017.htm? cmpid=copiaecola).

4. These results seem to be supported by the discussions exposed by Souza (2017) about how the "elite of backwardness" has implemented actions which expand the profit of private enterprises and destroy all possibilities for state or small cooperatives. 
demagogy and legitimized excesses that sometimes seem to be accepted as inevitable realities; "the pimping of life (Apple, 2018; Rolnik, 2018; Souza, 2017; Coburn and Gormally, 2017; Davies, 2017; SaglioYatzimirsky and Landy, 2014; Aued and Vendrani, 2009; Bubules and Torres, 2004; Santos, 2003; Pérez Gómez, 1998).

This movement creates a scenario of structural violence, which refers to the production and maintenance of social inequality and oppression and involves mechanisms by which social systems produce and normalize exclusion and marginalization. Moreover, it involves systematic attacks on human beings, their dignity and self-esteem, operating also through the symbolic sphere.

According to Souza (2017), from the perspective of culturalism which permeates our society, certain ideas of the supremacy of a certain group over others are naturalized and powerful to such an extent that they dominate subjects in an absolute and silent way. This interweaves complex views of who people are and how they may react towards others. Souza (2017) explains that this racism, disguised as culturalism, legitimates and enslaves the oppressed groups, in a colonization of both mind and body.

Yet, this conjuncture of social inequalities and dramatic contradictions can still foster new possibilities of actions (Santos, 2003). According to Santos (2003), terrible circumstances which systematically destroy people may get them involved in supporting socio-political interests and not just economic ones. Therefore, contradictions would turn out not as a form of paralysis, but as a means of transformation.

Thus, a socio-historical-cultural stance, as initiated by Vygotsky, seems to become the necessary force, not to generate destruction or alienation, but the movement towards transformation. Freire ([1970] 1987) pointed to the need to live the utopia and the search for the viable unheard of. In other words, to live a project that goes beyond the limiting situations posed by immediate reality, whose strength is

5. According to Rolnik (2018: 32), the capitalist economy has created such a level of exploitation of the labor force and the intrinsic cooperation of production to extract the surplus value, that it should be called a pimp, "to give it a name that tells precisely the frequency of vibration of its effects on our bodies". 
in realizable solutions, but not yet known or conceived. This condition requires the critical immersion of individuals in their known realities and broad emersion in multiple contexts of understanding, which broaden their horizons of perception.

In line with that, Stetsenko (2017) suggests transformative activity as an enactment of change based on the orientation to the future and the value-laden directionality of social practices. She states that ethical and purposeful dimensions are inherent in people's actions and they are "integral to acting and realizing the world in collaborative transformative practices and, therefore, to knowing and being as well" (Stetsenko, 2017: 231).

\section{How can education contribute towards the understanding of contradictions as triggers for transformation?}

Dayrell (2007) explains that school could be seen as one of the space-time where youth can exchange the social experiences they have had and recreate possible experiences as well. He explains that mostly schools attempt to impose a homogeneous and monolithic reality, where norms and rules are used to unify and standardize actions. This way, schools become a dialectical context for alliances and conflicts, imposition of rules and collective and individual strategies, transgressions and deals. In the process of becoming students, young people transform schools and are transformed by them. As stated by Stetsenko (2017: 171), "reality is constantly realized, changed, and recreated through the dialectics and movements of social communal practices embodied in human acts of being, knowing, and doing". In other words, young people at schools can be seen to collaboratively transform the circumstances of school life/education and in this process, are themselves transformed.

In this perspective, becoming students would also be understood as engaging in an "arena of human historical quests and pursuits, enacted as collective efforts at becoming fraught with contradictions and conflicts -infused with dimensions of values, interests, struggles, power differentials, and intentionality including goals, visions, and 
commitments to the future" (Stetsenko, 2017: 179). Towards that, the school's role should be to overcome stereotypes used as knowledge tools (Pérez Gómez, 1998). In a reality in which the reification of individual and social existence prevails, it is difficult to think of the role of schools as a tool that can contribute to the social construction of reality.

Schools seem to ignore the dialectics of human development between the real and the possible. The absence of a curriculum that integrates life and knowledge that goes around in schools seems to create a gap where it is not possible to see how school contributes to facing life and vice versa. Similarly, it is urgent that dealing with knowledge, curriculum and culture can be rethought as a piece of work "to overcome the fatalistic understanding of the situations of our contexts" (Freire, [1979] 2001: 37), so that it can exist to promote the participation of every citizen who is involved in it.

In line with that, Brazilian Digit-M-Ed ${ }^{6}$ project, the collaborative school project focused in this study, promotes a process of curriculum de-encapsulation, which leads to the understanding of how school knowledge, usually fixed and marked by unique and absolute true perspectives, can be overcome by an ecology of knowledges (Santos, 2008), derived from different sources. This diversity of possibilities creates the opportunity for the expansion of learning (Engeström, [1987] 2002), allowing possibilities for the learning processes outside of capsules when it comes to talking about the participants, the sources and the educational institution itself. Thus, this process triggers a type of human development in which the school actors extend their various types of knowledge beyond school and integrate them into their lives, transforming themselves and their realities. In other words, they learn ways to become transformative agents (Stetsenko, 2017) in their communities.

Coupled with that, this project is concerned with the discussion of hopelessness and lack of interest of young people and children in school and focuses on rethinking the school curriculum, the roles of the ones involved in school and their ways of acting, considering new possibilities. This concern makes room for more turbulent and

6. Digital Media Education. 
dialectical situations where diversity seems to be replaced by what Vertovec (2007) named as superdiversity. Superdiversity, initially directly related to migration issues, is characterized as the blending and interweaving of diversities in terms of an abundance of significant variables that affect where, how and with whom people live. In this complexity, it is possible to describe features suggesting both integration and the lack of it (Blommaert, 2013). This creates a new perspective to the concept of "otherness", which become a continuous flow (Blommaert, 2013:11). In this paper, superdiversity can be viewed as the perception and recognition of a myriad of additional and/or contradictory forms of being and acting in the world, intertwined, in a given space and time and also within each person in their process of becoming (Liberali, 2017).

More particularly, in this project, the roles of researchers, coordinators, supervisors, principals, teachers, interpreters of Brazilian sign language (Libras)/Portuguese and the deaf and hearing students transformed while they engage in activities for the construction of school proposals in order to break representational limits and promote new forms of de-encapsulation and transformation of their superdiverse realities. Such process is expanded as one that allows the broadening of the participants' action horizons beyond the functions and duties currently assigned to them, creating foundations for the development of mobility. This perspective of de-encapsulation implies thus to consider the range of discourses used by the participants, taking into account different degrees of power, authority and validity. It suggests promoting discourses in which human agency and social change are central.

In this respect, language can be understood in terms of mobility (Blommaert, 2010) created by different multimodal resources used by individuals (Kress, 2010). Thus, the focus of the work to be developed is based on the construction of meanings and power relations, generated by different uses of verbal-visual aids. Each action would be related to social orders, which are based on historical connections between current and previous statements. That creates what Blommaert (2010: 153) calls indexical orders which means "historical patterns and processes in which language-ideological perceptions of (desired) stability and predictability of language forms emerged". Indexical orders are responsible for determining feelings of belonging, identity and roles 
in society. As well as that, they define what is and what is not "good", "normal", "adequate" and "acceptable".

According to Blommaert $(2014,2015)$, based on the concept of Bakhtin's chronotope ([1937-38] 1998), mobility involves using the experiences of a space-temporal context as a basis for the construction of new possibilities of acting and producing meanings in new and/or different socio-cultural and historical contexts. Therefore, individuals are called to develop and expand repertoires - resources and opportunities established on ongoing previous contexts - built over personal biographies and social systems stories (Blommaert and Backus, 2012). These repertoires are architected in a never ending process and are established by means of the trajectories of each of these individuals throughout their lives. These paths provide the potential to play certain social roles, producing certain identities and inhibiting others.

In this sense, in line with Stetsenko (2017), schools should create opportunities for all members of the school Community to developing processes of being-knowing-doing. With that, they create activist endeavors premised on commitments to contributing to a sought after future in a world shared with others. Besides, they learn to cocreate the world and to be in it, developing individual and collective agency, and experiencing education as indispensable in providing the tools of activism and agency.

\section{Context and Participants}

The Brazilian research group 'Language in Activities in School Contexts' (Linguagem em Atividades do Contexto Escolar - LACE) has developed a collaborative school project, the Digit-M-Ed Hyperconnecting Brazil Project ${ }^{7}$, as a response to the demands perceived in society in the research and practices of the researchers and practitioners of the group. Some social, political, economic and cultural issues are at the basis that triggered this project: all types of

7. For more about the project refer to Liberali et al., 2017; Liberali, Magalhães et al., 2017; Liberali et al., 2015; Damianovic et al., 2016; Liberali, Clarissa, 2015; Pêssoa, 2016; Rittner, 2014. 
social exclusion such as age, gender, class, race, hearing differences; oppression lived by educators and students; children and teenagers who work on streets as opposed by others who have a very limited perception of the surrounding reality; students involved with drugs, both as users and as dealers, students who consider suicide as an option, and other similar dramatic circumstances.

Considering these conditions that permeate realities of the schools, participants of LACE Research Group developed school communities' formative proposals in a critical-collaborative way. Since 2013, from the international project, coordinated by Kontopodis et all. (2017) and funded by the Interchange Project Marie Curie International Research Teams - European Union FP7 (IRSES) (2012-2014), the extramural project, DIGIT-M-ED/Brazil - Transforming teaching and learning through multiple media (2013-2015), has been developed in Brazil. Later, the project was expanded as DIGIT-M-ED Hiperconectando Brazil - Transforming teaching and learning (2016-2017).

This project which involves a critical-collaborative intervention research (Magalhães, 2011) with private and public (municipal and state) schools from São Paulo focuses on a university-schoolcommunity partnership for the joint construction of de-encapsulated curricular proposals. The project, also expanded to Ceará and Piauí, is being held in institutions of higher and basic education, and involves (deaf and hearing) students, researchers, sign language interpreters, principals, coordinators, teachers and any other participants in the school community.

With a view to providing committed participation and to establish social and critical students', educators' and researchers' development, the involvement of these participants in the research becomes essential. In order to do that, the project has different participants:

- Teams of researchers - composed of doctors, masters and doctoral students, master's and undergraduate (graduate and primary and secondary education) from $\mathrm{PUC}^{-\mathrm{SP}^{8}}$ and other partner institutions - responsible for developing the theoretical basis and constant analysis of the data generated by the project activities. 
- Teams of teacher educators as formative groups - composed of some of the researchers also responsible, along with the project coordinators, for the organization of workshops and for the direct monitoring of schools and processes in developing each of them, through school observation, meetings, and reflective sessions. As the collaborators in the development of curriculum proposals, they become responsible for the discussions with principals, coordinators, students and teachers (everyone as teacher educators); and for developing proposals that are relevant and appropriate to the context of each institution.

By doing so, it is important to note that the participants of the focus schools also have specific functions:

- Principals and pedagogical coordinators - participants who monitor and carry out the process of the training and implementation of the project in their schools, backing the researchers and the formative groups, monitoring the staff training.

- Support group - the group of two to four teachers from each school, who take the lead with the coordinators and studenteducators to conduct the training of the institution's teaching staff. As colleagues, they support and conduct the others' training, creating ties of cooperation in achieving shared objectives for the development of all.

- Student-educators (ten to thirty students from each school), as members of youth culture, they become trainers of the researchers, principals, coordinators, teachers and other students. They take turns in participating in monthly meetings held with other schools.

In the project, the participants become each others educators and engage in studying, training and monitoring the others' development in a collective transformation cycle. The activities carried out in the project that are data source include:

- Meetings (weekly) with researchers and sign language interpreters for preparation and reflection about activities developed with the teacher educators, and about activities in 
the schools - about 20 researchers are involved in these weekly meeting;

- Workshops (monthly) with researchers, sign language interpreters, principals, coordinators, teachers and students about 80 participants gather at PUC-SP for these meetings. Due to lack of room, each school is asked to take only 10 participants to the meetings, although in most schools the number of participants in the formative groups is much higher (including principals, coordinators, teachers, students and, in some schools, parents);

- Meetings (every fortnight or depending on the schools' availability) with students, teachers, coordinators and principals of the schools;

- Classes or school projects (depending on the schools' availability) with teachers and students who participate in the monthly collective meetings;

- Scientific events organized by the research group where all participants present the results of the activities of the project.

Since 2013, the project has been organized to deal with topics that are relevant to the Brazilian community (2013: demonstrating positions; quality of life; 2014: school identity; what to do with garbage; 2015: gender issues; urban mobility; 2016: differentiating public and private issues; 2017: "nósoutros" (ourselves). Besides these issues, it has focused on human activities that were thought as central for the organization of the school curriculum (2013: participating in demonstrations; 2014: creating films about school realities; taking care of trash; 2015: going to parties; moving around the city; 2016: making and keeping friends; and 2017: occupying the city). Moreover, some pedagogical contents were debated with the participants as a way to organize how schools could evaluate and reconstruct their practices (2013: multiliteracies ${ }^{9}$ : multiculturality, multimedia, multimodality; 2014: multiliteracies: situated practice, overt instruction, critical framing, transformed practice; 2015: social activity $^{10}$ as curriculum

9. New London Group, [1996] 2000; Rojo, 2012, 2013.

10. Liberali, 2009; Carvalho, Santiago, and Liberali 2014; Liberali and Santiago, 2016. 
organizers; 2016: play $^{11}$ as the organizers of school practices; and 2017: argumentation $^{12}$ as the means for dialogical interactions).

For the purpose of this article, the focus will rely on some of the activities developed in 2017. From its beginning, the project has combined different schools, however, the main schools ${ }^{13}$ involved in the project in 2017 were: four public schools [EMEF Eda Terezinha Chica Medeiras (2013), EE Adenilson dos Santos Franco (2016), EE Professor José Sérgio Pereira (2016), EE. Maria Helena Faria Lima e Cunha (2017)] and three private ones - Stance Dual School (2014), Colégio Stagio (2014), Colégio do Instituto SELI (2015).

In 2017, the main theme (Nósoutros/ Ourselves) was chosen as a result of the reflections about problems derived from the terrible interactions that have been occurring in the social media regarding people with differing perspectives, forms of being, and ways of acting. Although multiculturalism is regarded as a natural reality, not everyone seems to know how to deal with diversity. Many difficult circumstances were debated and expressed by the participants in the end of 2016 . Besides, some of the researchers visited and were very much influenced by the exhibition, "Ourselves", by Bob Wolfenson, a famous Brazilian photographer, in February 2017.

According to the photographer, his observation of pedestrians waiting to cross a street in New York led him to reflect about what made them similar and at the same time so singularly different. This consideration triggered his desire to "organise scenes like that in different places around the world, highlighting one of the most striking paradoxes of the human being, so evident in that first registered moment: that of being alike yet different, the desire to be part of a group and at the same time, the need to stand out ${ }^{14}$.

The combined demand of our political and social reality and the impact of the exhibition created the basis for the choice of the theme of the year. Following the same idea, the choice to develop argumentative

11. Lobman and Lundquist, 2007; Holzman, 2009; Connery et al., 2010.

12. Liberali, 2013, 2016.

13. The schools authorize the use of their names. 
interactions was central to the construction of critically oriented discussions. Both educators and students had shown, in previous years, a demand to construct strategies to participate in discussions about difficult issues. Learning to present positions, supports, counterarguments, solutions or deals was central. The main concern was: through which activities of everyday life would this take place?

In previous years we had discussed about mobility in the city and how different neighborhoods, streets and locations were organized. Many students from impoverished communities had few experiences in more wealthier regions and the other way around. Besides, reports stated they lacked ideas about how to participate in the activities that were part of their city cultural events. Regarding the fact that there had been issues with immigrants, drug users, street vendors, and commuters, the activity of occupying the city seemed to be a central one for the group. So, in the first semester of 2017, the project centered its proposals around discussing about "ourselves", learning to develop argumentative interactions and occupying the city.

Some of the proposals presented had the following subject areas as their focus:

\begin{tabular}{|l|l|}
\hline Proposals & Subject Areas \\
\hline $\begin{array}{l}\text { Carnival on Praça } \\
\text { Roosevelt }\end{array}$ & $\begin{array}{l}\text { Geography (different regions /zone -place, space, territory, } \\
\text { memory, identity, expansion: city center and periphery, public } \\
\text { policies) } \\
\text { Language: presenting and supporting points of view }\end{array}$ \\
\hline $\begin{array}{l}\text { Taking photos of } \\
\text { "Ourselves" }\end{array}$ & $\begin{array}{l}\text { Geography (city vulnerabilities, cultural, sportive, artistic, } \\
\text { political social manifestations) } \\
\text { Language: Oral presentation (multimodality) - photos }\end{array}$ \\
\hline "Rolê" / "Going & $\begin{array}{l}\text { Math (worksheet, spreadsheet, graphs, calculating the average, } \\
\text { cross multiplication, currency, problem resolution) } \\
\text { Geography (urban occupation: leisure and occupation, } \\
\text { mobility) } \\
\text { Cross disciplinary: Conceptual Map } \\
\text { Language: how to present and support a position }\end{array}$ \\
\hline
\end{tabular}

* This was a demand, apart from the topic of the semester, because some of the students in our group got involved with suicidal games. For more discussion on this refer to Liberali (2018, forthcoming). 


\begin{tabular}{|l|l|}
\hline $\begin{array}{l}\text { Playing a Blue } \\
\text { Whale like game* }\end{array}$ & $\begin{array}{l}\text { Language: how to present and support a position } \\
\text { Cross disciplinar: conceptual Map }\end{array}$ \\
\hline De-occupy & $\begin{array}{l}\text { Geography (urban occupation: public policies, job and } \\
\text { Crackland }\end{array}$ \\
& $\begin{array}{l}\text { Language: how to present and support a position; how to } \\
\text { disagree, how to strike a deal. }\end{array}$ \\
\hline
\end{tabular}

These proposals were turned into real activities during the monthly meetings with the schools, which gathered about 80 participants (researchers, sign language interpreters, principals, coordinators, teachers and students). For the purpose of this paper, Carnival on Praça Roosevelt and De-occupy Crackland will be discussed.

\section{Carnival on Roosevelt Square}

Sao Paulo does not have a strong tradition as a Carnival city; however, in recent years, as part of the actions organized by the city mayor to occupy the city for cultural activities, street parties ('blocos') have increased their popularity. In 2017, many revelers went to the streets to celebrate carnival, with extravagant costumes and catchy music. During the weeks surrounding carnival, São Paulo's streets were full of celebrations and one of its main location was Roosevelt Square, a square boxed in by high-rise apartments in downtown São Paulo.

Neighborhood associations threw roving, ragtag block parties, but on the last day of the celebrations, police and revelers had a confrontation on Roosevelt Square. Officers resorted to tear gas and rubber bullets to quell a confrontation while they were attacked with bottles, rocks and pieces of wood. The trouble began around 12:00am, when some neighbors called the police to disperse the crowds. The city and state government supported the actions of the police as well as some of the neighbors. The revelers complained about the type of reaction the police had against them and said it was not 1:00am yet, the time set for the parties to finish, according to the city government's security plan.

This episode was the trigger for the first proposal to discuss urban occupation in the city of São Paulo, focusing on the geography concepts of place, space, territory, memory, identity, expansion, focusing on the 
study of the city zones and their rules. Besides, different sources and types of genre were used so the participants could have ample access to different perspectives and different contexts where this discussion was circulating. In terms of language, the focus was on using connectives to present support opinions. Participants were supposed to read and watch videos on the theme and discuss a controversial question: should Roosevelt Square be a free space for Carnival celebrations? By using their own knowledge of the topic researching on the internet and using material provided by the researchers, they had to evaluate the situation and come up with ideas for Carnival 2018.

The different tasks organized for this proposal involved:

\begin{tabular}{|c|c|c|}
\hline Tasks & Description of the task & $\begin{array}{c}\text { Theoretical } \\
\text { concepts worked } \\
\text { with }\end{array}$ \\
\hline $\begin{array}{l}1 \text { - invitation } \\
\text { for a Digit-M- } \\
\text { Ed carnival } \\
\text { activity on the } \\
\text { first meeting }\end{array}$ & $\begin{array}{l}\text { Each school was supposed to create a carnival song } \\
\text { using the themes from Digit-M-Ed } 2017 \text { or their } \\
\text { own relationship to the project as the basis topic for } \\
\text { the song. This involved sharing the lyrics, a video } \\
\text { or a recording of the song created by the school, in } \\
\text { our collective WhatsApp group, to be used during } \\
\text { the meeting. Also, participants were invited to come } \\
\text { to PUC-SP in their carnival outfits. }\end{array}$ & $\begin{array}{l}\text { Multimedia } \\
\text { Situated practice } \\
\text { Play } \\
\text { Social activity }\end{array}$ \\
\hline $\begin{array}{l}2-\text { Carnival } \\
\text { party at PUC } \\
\text { with neighbors } \\
\text { complaining } \\
\text { and police try- } \\
\text { ing to disperse } \\
\text { the activities }\end{array}$ & $\begin{array}{l}\text { PUC auditorium was organized as a carnival place } \\
\text { with signs of Praça Roosevelt spread everywhere. } \\
\text { However, no mention about it was made. } \\
\text { A game was proposed. People could party as much } \\
\text { as they wanted but when the music stopped, they } \\
\text { had to freeze and observe what was going on around } \\
\text { them. This happened twice. } \\
\text { Music was played, and everybody was singing and } \\
\text { dancing. After a few minutes, researchers pretend- } \\
\text { ing to be neighbors started shouting against the party } \\
\text { goers. Music was stopped, and people froze. } \\
\text { After music was resumed, the police entered and } \\
\text { started shouting and "attacking" the revelers (most- } \\
\text { ly other researchers who were violently "arrested"). } \\
\text { Once more, music stopped, and participants froze } \\
\text { and observed the scene. } \\
\text { The researchers asked everyone to sit and talk about } \\
\text { what had happened. } \\
\text { After a while they were asked to compare what } \\
\text { they experienced to recent events ("What recent } \\
\text { events were similar to our performance?"). They } \\
\text { were then asked to present their conclusions to the } \\
\text { whole group }\end{array}$ & $\begin{array}{l}\text { Situated practice } \\
\text { Play } \\
\text { Social activity }\end{array}$ \\
\hline
\end{tabular}




\begin{tabular}{|c|c|c|}
\hline Tasks & Description of the task & $\begin{array}{c}\text { Theoretical } \\
\text { concepts worked } \\
\text { with }\end{array}$ \\
\hline $\begin{array}{l}3 \text { - Watching } \\
\text { videos and } \\
\text { discussing the } \\
\text { way the two } \\
\text { video news } \\
\text { clips presented } \\
\text { the situation }\end{array}$ & $\begin{array}{l}\text { After participants realized they had participated in } \\
\text { a recreation of the episode at Praça Roosevelt, they } \\
\text { were asked what they knew of the episode. Some } \\
\text { reported their ideas. As a sequencing task they were } \\
\text { all invited to watch two pieces of video news by two } \\
\text { different tv channels about the same episode. Later, } \\
\text { they had to discuss the similarities and differences } \\
\text { in the way the episode was reported. } \\
\text { ("Observe these two pieces of news about a recent } \\
\text { event. Which event is being reported? How were } \\
\text { they reported? Are there similarities between the } \\
\text { news? Are there differences? What are they?") }\end{array}$ & $\begin{array}{l}\text { Overt instruction } \\
\text { Multiculturality } \\
\text { Multimodality } \\
\text { Multimedia } \\
\text { Argumentation }\end{array}$ \\
\hline $\begin{array}{l}4 \text { - Reading } \\
\text { and gathering } \\
\text { information } \\
\text { as supporting } \\
\text { arguments for } \\
\text { actions to be } \\
\text { taken for } 2018\end{array}$ & $\begin{array}{l}\text { For this task, participants received links to maps, } \\
\text { texts, digital book, facebook pages, letters, laws and } \\
\text { were also invited to research on their own in order } \\
\text { to gather information which could be transformed in } \\
\text { supporting arguments on the topic to be discussed: } \\
\text { should Praça Roosevelt be a free space for Carnival } \\
\text { celebrations? } \\
\text { First, the big group was divided in four different } \\
\text { classes. In each class, in smaller groups, participants } \\
\text { from different schools had to be subdivided for } \\
\text { discussions with partners with the same position. } \\
\text { They were supposed to search for data to support } \\
\text { their positions and to counter argue the other per- } \\
\text { spective. After some time discussing and organizing } \\
\text { the data, they had to present their findings to their } \\
\text { groups with different positions in oral presentations. } \\
\text { As a result of this, the whole class was supposed } \\
\text { to build a number of suggestions to be presented } \\
\text { for Carnival } 2018 \text {. }\end{array}$ & $\begin{array}{l}\text { Overt instruction } \\
\text { Critical framing } \\
\text { Multiculturality } \\
\text { Multimodality } \\
\text { Multimedia } \\
\text { Argumentation }\end{array}$ \\
\hline $\begin{array}{l}5-\text { Perfor- } \\
\text { mance of the } \\
\text { presentations } \\
\text { of the delib- } \\
\text { erations in the } \\
\text { plenary with } \\
\text { all four classes }\end{array}$ & $\begin{array}{l}\text { Representatives of each of the four classes, from } \\
\text { different schools, different ages, social-economic } \\
\text { groups, hearing and deaf presented, in } 3 \text { minutes, } \\
\text { their collective solutions to the whole group who, } \\
\text { then, could make their own commentaries in one } \\
\text { minute. }\end{array}$ & $\begin{array}{l}\text { Transformed } \\
\text { Practice } \\
\text { Multiculturality } \\
\text { Multimodality } \\
\text { Multimedia } \\
\text { Argumentation } \\
\text { Play } \\
\text { Social activity }\end{array}$ \\
\hline
\end{tabular}

The whole task contributed to developing and exemplifying the pedagogical concepts studied throughout the year by the groups. For example, the main Multiliteracies (New London Group, [1996] 2000) discussions on multiculturality, multimedia, multimodality, situated practice, overt instruction, critical framing, and transformed practice were covered in the different tasks. The diversity of positions and 
ways of the discussion offered the participants access to an ecology of Knowledge (Santos, 2008), derived from different sources, creating a multicultural understanding of the context under scrutiny. Besides, the multiple media used such as videos, news, books, social media webpages created varied access points and multiple possibilities to grasp meaning through different modes. These modes were questioned as part of the discussions, offering participants critical lenses to guide their participation in the discussions.

As for the organization of the tasks, participants were involved in situated practices which both recreated in a play like situation and brought recent facts of the city daily life under scrutiny. Departing from that, an overt study of Geography was materialized by means of the search for maps, zone descriptions, analysis and observations about the city laws and History, among others. All these discussions were carried out through critical evaluations of the positions assumed and how these positions could be grounded by explicit supporting arguments. Finally, participants were called to deliberate about the following year carnival in an effort to create a possible transformed practice and a means to realize transformative stances (Stetsenko, 2017).

In this exercise in Multiliteracy, participants had the chance to deal with contradictory perspectives of reality but these contractions did not turn into a movement to defeat the other or to suppress their positions but as a means for the enactment of collaborative movements for change. The argumentative movement participants dealt with referred to dealing with values, interests, struggles, but, above all, the commitment with the creation of new possibilities of living (Liberali, 2018 in print).

Once the tasks were organized based on a common social activity "participating in a carnival street party", one of the possible ways to materialize urban occupation (which is the generic social activity of the semester), participants could engage in the tasks, learning school contents such as argumentative skills and Geography concepts as a means to become transformative agents (Stetsenko, 2017). The tasks were carried out through play activities in which participants were called to have a critical immersion in reality-like situations and an emersion with multiple possibilities of acting in everyday life. Through playing with the social activity, analyzing it through multiple media, multiple 
perspectives and multiple resources, participants develop repertoires to to engage in similar contexts, thus expanding their mobility.

\section{De-occupying Crackland}

Brazil is one of the world's largest markets for crack cocaine and the city of Sao Paulo is the home to intense poverty, homelessness and the nation's largest criminal organization, which provides Crackland with both its supply of the drug and ample demand for it. Crackland is a homeless encampment where crack and other drugs are openly consumed and sold and where a high level of violence occurs. The discussion about De-occupying Crackland was triggered by an action by the mayor of São Paulo, João Doria, who demanded the de-occupation of the place in June, 2017.

As a result of this attempt at street clearance, 500 armed police officers of São Paulo advanced on crack addicts and homeless people. In the episode, nearly 40 people were said to be arrested while others fled to neighboring streets. Besides this, the police used bulldozers to clear the shacks and tents set up by the addicts and sealed off abandoned buildings they had occupied. In order to do that, the police sometimes used rubber bullets and tear gas. Before this, the previous mayor, Fernando Haddad, had implemented a program that offered addicts housing and a small daily sum for jobs such as road-sweeping or gardening, but this was substituted by a project that was more oriented towards police actions and in-patient treatment.

The episode triggered differing perspectives: some agreed with the need for intensive policing in the area and even suggested that addicts should receive compulsory rehabilitation treatment. According to some advocators of this view, the place could be described and called: a "human zoo", a "horror show", or even a "zombie tourist attraction". Others, however, argued that the police are haphazard, often violate the rights of the users and actions taken may be driven by business demands to clean up a piece of potentially valuable land. They believe the new mayor's campaign for a "beautiful city" involves actions to "sanitize" the city and they complain that there are no offerings of new opportunities, except for in-patient treatment. 
These discussions took up social media and involved people of all ranks of life in heated debate about the lives and whereabouts of the people who were involved with Crackland. This happened on the weekend prior to the monthly Digit-M-Ed meeting involving all participants and researchers decided to bring this issue for the discussion once it involved the theme of the year "ourselves", the social activity "occupying the city", and triggered the need for collaborative argumentative interactions which could counterbalance the types of discourse that were spread in social media and different groups, Family and political debates. In order to do that, how to present and support a position, how to disagree, and how to strike a deal became the focus of the discussion. Furthermore, discussions about urban occupation from the perspective of public policies, mobility, job and occupation were central.

The different tasks organized for this proposal involved:

\begin{tabular}{|c|c|c|}
\hline Tasks & Description of the task & $\begin{array}{c}\text { Theoretical } \\
\text { concepts } \\
\text { worked with } \\
\end{array}$ \\
\hline $\begin{array}{l}1 \text { - inquiry } \\
\text { discussion }\end{array}$ & $\begin{array}{l}\text { In groups of about } 15 \text { people, participants were asked } \\
\text { to research about the following issues: "what is } \\
\text { Crackland and how was it formed?", "how do people } \\
\text { from different backgrounds live at Crackland?", "who } \\
\text { defines the way Crackland is organized?", and "how } \\
\text { is space occupied in Crackland?". In order to do } \\
\text { that, they were presented with printed, TV and radio } \\
\text { news, with different interlocutors offering their views. } \\
\text { Apart from that, they were invited to research on the } \\
\text { internet about the history of the neighborhood where } \\
\text { Crackland is situated. The differences in background } \\
\text { of the students (some very wealthy and others, very } \\
\text { poor) made it possible for them to have access to fresh } \\
\text { and vivid ideas about Crack dealers. Participants from } \\
\text { poor communities were invited to describe and explain } \\
\text { numerous aspect of the lives of those who use, sell and } \\
\text { organize drug traffic. Some of the wealthier participants } \\
\text { brought to the discussion their perspectives on the issues } \\
\text { which many times derived from the fact that they were } \\
\text { also users of some types of drugs. This gave support for } \\
\text { them to reflect in a more empathic perspective towards } \\
\text { the positions expressed. }\end{array}$ & $\begin{array}{l}\text { Situated Practice } \\
\text { Overt Instruction } \\
\text { Critical Framing } \\
\text { Multiculturality } \\
\text { Multimedia } \\
\text { Multimodality } \\
\text { Argumentation }\end{array}$ \\
\hline $\begin{array}{l}2- \\
\text { Performance } \\
\text { of a lifetime }\end{array}$ & $\begin{array}{l}\text { Participants in each group put together ideas of } \\
\text { "ourselves", "occupying the city" and "de-occupying } \\
\text { Crackland" and set up an artistic performance, } \\
\text { expressing how they viewed the situation and what } \\
\text { perspectives could be set for the topic discussed. }\end{array}$ & $\begin{array}{l}\text { Transformed } \\
\text { Practice } \\
\text { Play } \\
\text { Social Activity }\end{array}$ \\
\hline
\end{tabular}




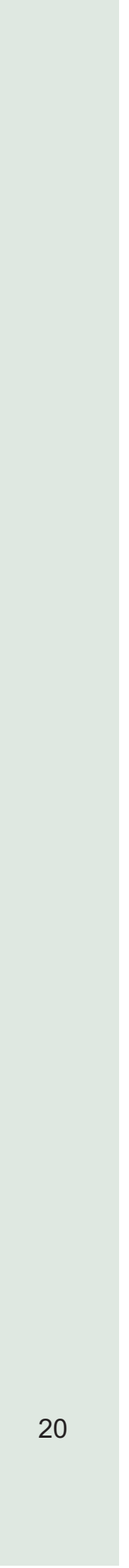

Although this activity was faster than the one about Carnival, it also encompassed all the pedagogical concepts discussed in the project as we can see below.

Multiculturality, multimedia, multimodality (New London Group, 1996[2000]; Rojo, 2012, 2013) were the basis for the proposal and inquiry approach taken. In order to conduct the tasks participants were supposed to use a great variety of multimodal texts (printed, TV and radio news, among others) with various positions and group representatives (police, neighbors, politicians, drug users, homeless people, workers of the region). Besides that, the discussions of their findings were infused by personal experiences with the context under analysis and similar ones as a means to create a closer understanding of the situation. This process offered participants the opportunity to access a real situation (situated practice) as a point of departure for the overt discussion of the Geography concepts and the overt development of argumentative skills. They could engage with critical discussions and use their argumentative and affective skills to deal with a very complex topic, which could trigger contradiction.

In this activity, participants were involved with the social activity of occupying the city and had to reflect about their lives and how it was impacted by the circumstances of Crackland and drug trafficking and use. Also, they were able to talk about the creation of a community in the context of Crackland and what constituted a community. In the final task, the artistic performance created a bind among participants who had to follow the rules of creating a three-minute performance with the topic provided and with commitment towards some kind of expansion of the context.

The violent situation of Crackland and its de-occupation materialized a contradiction that has taken up discussions in the city, in particular, and in the country as a whole. The debate opened up for the observation of ethical dimensions inherent in people's actions and for the careful realization of alliances and conflicts, imposition of rules and collective and individual strategies, transgressions and deals. By positioning themselves in relation to their personal and collective perspectives, participants had access to superdiverse realities and developed resources related to how to understand, discuss and 
deliberate about their common realities. The participants could develop repertoires to act in new ways in new trajectories they may get engaged with both on how to participate in discussions of disputed topics and on how to understand the social situation of homeless people, drug addicts, users and dealers. In by doing do they had the chance to become transformative agents (Stetsenko, 2017) who can later contribute to the expansion of the ways of living and the transformation of these oppressive conditions.

\section{Concluding Remarks}

The two proposals exemplify how the Digit-M-Ed Project, as a collaborative project, created opportunities for transforming urban education. Likewise, the experience participants have had in the project trigger the development of similar activities in their schools and new formats for school curriculum. These types of school proposals are not common in Brazil. Mostly, schools are involved with plans for the best way to instruct students with the largest, most updated and adequate contents, normally demanded by all kinds of assessment. The main focus seems to rely on students' content and cognitive development with an almost complete disregard for their affective, collective, transformative dimensions. In this way, they act to reproduce the social, economic, political, cultural context as it is. Little does it contribute to collaboratively transform the school and community life.

The participation in the project involves both living and creating curriculum proposals for the materialization of the viable unheard of. In a Freirean perspective, the experiences lived in the project offer participants the chance to live and act beyond the limiting situations of immediate reality. They help create the necessary repertoire for a critical immersion reality and the expansion of their possibilities of being.

Following Stetsenko's (2017) suggestion for a Pedagogy of Daring, engaging in school proposal such as the ones developed in Digit-M-Ed project involves:

- processes of being-knowing-doing - Participants have to rethink who they are, what they know and how they intend to act 

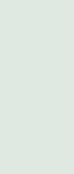

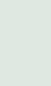
(1)

with the new repertoires they have access to through the social activities which organize the way the curriculum is organized.

- creating activist endeavors premised on commitments to contributing to a sought after future in a world shared with others - the situations that are enacted through diverse media, modes of representations and perspectives became the basis for participants to reflect about the present and past situations they had and deliberate critically about new possibilities.

- cocreating the world and being in it - the topics and ways of acting were collaboratively orchestrated, therefore, participants had to learn more about their own and others' ways of being in the world and take stance about how they wanted their collective participation to be.

- developing individual and collective agency - all participants had to contribute to the development of the whole group and their schools. This demanded not only that they took responsibility for their own actions but that they engaged the others in doing that as well.

These characteristics prompted an experience in education as a means to developing transformative stances because by participating in the project all participants became part of the transformation they were observing, living, analyzing, criticizing, deliberating about and transforming.

\section{Referências}

APPLE, Michael. 2018. The struggle for democracy in education. In: APPLE, Michael; GANDIN, Luis Armando; LIU, Shuning.; MESGULAM, Assaf; SCHIRMER, Eleni. The struggle for democracy in education: lessons from social realities. New York: Routledge.

AUED, Bernadete Wrublevski; VENDRANI, Célia Regina. 2009. Persistência do trabalho infantil na indústria e na agricultura. Florianópolis: Insular.

BAKHTIN, Mikhail Mikhailovich. [1937-38] 1998. Formas de tempo e de cronotopo no romance: ensaios de por ética histórica. In: BAKHTIN, 
Mikhail Mikhailovich. Questões de literatura e estética - a teoria do romance. São Paulo: Unesp.

BLOMMAERT, Jan. 2015. Chronotopes, scales and complexity in the study of language in society. Annual Review of Anthropology. v. 44, 105-116. doi.org/10.1146/annurev-anthro-102214-014035.

.2014. From mobility to complexity in sociolinguistic theory and method. Cambridge University Press., 242-260. doi.org/10.1017/ CBO9781107449787.012.

2013. Citizenship, language and superdiversity: towards complexity. Journal of Language, Identity \& Education. 193-196. doi.org/10.1080/15348458.2013.797276.

2010. The Sociolinguistics of Globalization. Cambridge: Cambridge University Press.

BLOMMAERT, Jan; BACKUS, Ad. 2012. Superdiverse repertoires and the individual. In: SAINT-GEORGES, Ingrid; WEBER, Jean-Jacques (Eds.). Multilingualism and Multimodality. The future of education research, p. 11-32. doi.org/10.1007/978-94-6209-266-2_2.

BURBULES, Nicholas; TORRES, Carlos Alberto. In: BURBULES, Nicholas; TORRES, Carlos Alberto (Eds.). 2004. Globalização e Educação: uma introdução. Porto Alegre: Artmed Editora.

CARVALHO, Marcia Pereira; SANTIAGO, Camila; LIBERALI, Fernanda Coelho. 2014. Atividade social e multiletramento: um novo olhar para o ensino-aprendizagem de língua inglesa para crianças em contexto de escola pública. v. 6. Fólio - Revista de Letras: Vitória da Conquista.

CONNERY, Cathrene; JOHN-STEINER, Vera; MARJANOVICSHANEEDS, Ana. 2010. Vygotsky and Creativity: a cultural-historical approach to play, meaning making, and the arts. New York: Peter Lang.

COBURN, Annette; GORMALLY, Gormally. 2017. Communities for social change: practicing equality and social justice in youth and community work. New York: Peter Lang.

DAMIANOVIC, Maria Cristina; SILVA, Shirley Adriana; CARRIJO, Viviane Letícia Silva; Farias, Angélica Miyuki. 2016. Argumentação multimodal entender colaboração: além da materialização linguística no Digit-M-ed. In: LIBERALI, Fernanda Coelho; DAMIANOVIC, Maria Cristina; NININ, Maria Otília Guimarães; MATEUS, Elaine; GUERRA, Mônica. (Eds.). Argumentação em contexto escolar: relatos de pesquisa. 1. ed. Campinas, São Paulo: Pontes Editora. 
DAVIS, Angela. 2018. A liberdade é uma luta constante. São Paulo: Boitempo.

DAYRELL, Juarez. 2007. A escola "faz" as juventudes?: reflexões em torno da socialização infantil. vol 28, 100. Educ. Soc. Campinas: Campinas.

ENGESTRÖM, Yrjö. [1987] 2002. Learning by expanding: an activitytheoretical approach to developmental research. Helsinki: Orientakonsultit.

FREIRE, Paulo. [1970] 1987. Pedagogia do oprimido. Rio de Janeiro: Paz e Terra.

[1979] 2001. Conscientização: teoria e prática da liberdade. São Paulo: Centauro.

HOLZMAN, Lois. 2009. Vygotsky at work and play. New York: Routledge.

KRESS, Gunther. 2010. Multimodality: a social semiotic approach to contemporary communication. London: Routledge.

KONTOPODIS, Michalis; VARVANTAKIS, Christos; WULF, Christoph. 2017. (Eds.). Global Youth in Digital Trajectories. Routledge: London.

LIBERALI, Clarissa Coelho. 2015. Análise teórico-prática sobre o multiculturalismo e a colaboração como formas de lidar com as diferenças. Trabalho de Conclusão de Curso. USP: SP.

LIBERALI, Fernanda Coelho. 2018. Argumentação na opressão destrutiva e na colaboração crítica: do cenário político do impeachment ao contexto do projeto Digit-M-Ed In: SZUNDY, Paula; TÍLIO, Rogério; MELO, Glenda (Eds.). Inovações e desafios epistemológicos em LA na América Latina. v. 1. Campinas, SP: Pontes Editores (in print). 2017. Globalization, Superdiversity, Language Learning and Teacher Education in Brazil. In: BANEGAS, Darío Luis (Ed.). Initial english language teacher education: international perspectives on research, curriculum and practice. $1^{\mathrm{a}}$ ed. New York: Bloomsbury.

; LIBERALI, Clarissa Coelho; PADRE, Brenda Treco; SANTOS, Jessica Aline Almeida. 2017. Mobilidade e Práticas Translíngues na Construção de um Mundo com Justiça Social: um Estudo no Projeto DIGIT-M-ED. In: ROCHA, Claudia Hildorf; EL KADRI, Michele Salles; WINDLE, Joel Austin. (Eds.). Diálogos sobre tecnologia educacional: educação linguística, mobilidade e práticas translíngues. $1^{\mathrm{a}}$ ed. v. 1. Campinas, SP: Pontes Editores, p. 237-267.

; MAGAlHÃES, Maria Cecília Camargo; MEANEY, Maria 
Feliciana; CABABE, Bruna Soares; SANTOS, Jessica Aline Almeida. 2017. Enhancing Multimedia Use In Public Middle and High Schools in São Paulo/ Brazil: A Critical Collaborative Methodological Perspective. In: KONTOPODIS, Michalis; VARVANTAKIS, Christos; WULF, Christoph. (Eds.). Global Youth in Digital Trajectories. $1^{\mathrm{a}}$ ed. London: Routledge, p. 127-145.

2016. Articulação entre argumentação e multimodalidade em contextos escolares. In: LIBERALI, Fernanda Coelho; DAMIANOVIC, Maria Cristina; NININ, Maria Otília Guimarães; MATEUS, Elaine; GUERRA, Mônica (eds.). Argumentação em contexto escolar: relatos de pesquisa. $1^{a}$ ed. Campinas, São Paulo: Pontes Editora, p. 63-78.

2016. Inglês: linguagem em atividades sociais. $1^{a}$ ed. v. 2. São Paulo: Blucher.

; MAGALHÃES, Maria Cecília Camargo; MEANEY, Maria Cristina; SANTIAGO, Camila; CANUTO, Mauricio; Santos, Jessica Aline Almeida. 2015. Projeto DIGIT-M-ED Brasil: uma proposta de desencapsulação da aprendizagem escolar por meio dos Multiletramentos. v. 10. Prolíngua: João Pessoa, p. 2-17.

; SANTIAGO, C. 2016. Atividade Social e Multiletramentos. In: LIBERALI, Fernanda Coelho. (Ed.). Inglês: linguagem em atividades sociais. $1^{\mathrm{a}}$ ed. v. 2. São Paulo: Blucher, p. 17-31.

. 2013. Argumentação em contexto escolar. $1^{\text {a }}$ ed. São Paulo: Pontes Editora.

. 2009. Atividade Social nas aulas de língua estrangeira. $1^{\mathrm{a}} \mathrm{ed}$. São Paulo: Moderna.

. Aprender brincando em perspectiva vygotskiana. São Paulo: Pontes Editora (in print).

LOBMAN, Carrie; LUNDQUIST, Matthew. 2007. Unscripted learning: using improv activities across the K-8 curriculum. New York, Teachers College Press.

MAgAlHÃeS, Maria Cecília Camargo. 2011. Pesquisa Crítica de Colaboração: Escolhas epistemo-metodológicas na organização e condução de pesquisas de intervenção no contexto escolar. In: MAGALHÃES, Maria Cecília Camargo; FIDALGO, Sueli Salles (Eds.). Questões de método e de linguagem na formação docente. 1 ed. Campinas, SP: Mercado de Letras, p. 13-40.

NEW LONDON GROUP. [1996] 2000. The Pedagogy of Multiliteracies: Designing Social Futures. v.66, n.1. Harvard Educational Review, p. 60-92. 
PÉREZ-GÓMEZ, Angel. 1998. La cultura en La sociedad neoliberal. $2^{\mathrm{a}}$ ed. Madrid: Morata.

PESSÔA, Everton. 2016. Multiculturalidade e colaboração crítica entre surdos e ouvintes na visão de um pesquisador tradutor-intérprete de Libras/Português. Dissertação (Mestrado) - Pontifícia Universidade Católica de São Paulo, São Paulo.

RITTNER, Guilherme Manzati. 2014. Digit-M-ed Brasil: a realidade possível do uso da tecnologia em sala de aula e suas implicações para desenvolver para habilidades de leitura e escrita em um ambiente de multiletramento. Monografia (Iniciação Cientifica) - Pontifícia Universidade Católica de São Paulo, São Paulo.

.2014. Interdisciplinaridade além da sala de aula: professores em parceria. Trabalho de Conclusão de Curso (Graduação) - Pontifícia Universidade Católica de São Paulo, São Paulo.

ROJO, Roxane.2013.Escol@ conectada os multiletramentos e as TICs. São Paulo: Parábola Editoral.

. 2012. Multiletramentos na escola. São Paulo: Parábola Editoral.

ROLNIK, Suely. 2018. Esferas da Insurreição: notas para uma vida não cafetinada. São Paulo: n-1 edições.

SAGLIO-YATZIMIRSKY, Marie-Carrie; LANDY, Frédéric. (Eds.). 2014. Megacity slums: social exclusion, space and urban policies in Brazil and India. London: Imperial College Press.

SANTOS, Milton. 2003. Por uma outra globalização. Rio de Janeiro: Record.

SANTOS, Boaventura de Sousa. 2008. A gramática do tempo, para uma nova cultura política. São Paulo: Cortez.

SOUZA, Jessé. 2017. A elite do atraso: da escravidão à lava jato. Rio de Janeiro: Leya.

STETSENKO, Anna. 2017. The transformative mind: expanding Vygotsky's approach to development and education. Cambridge University Press: New York.

VERTOVEC, Steven. 2007. Super-diversity and its implications. 30:6. Ethnic and Racial Studies. DOI: 10.1080/01419870701599465.

Recebido em: 07/10/2018

Aprovado em: 11/11/2018 